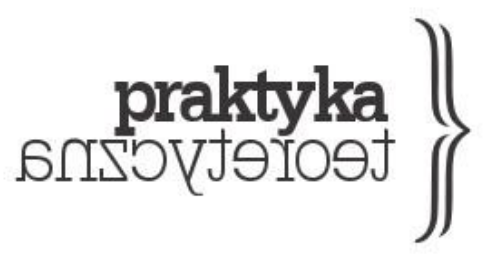

ISSN 2081-8130

DOI: $10.14746 /$ prt.2017.2.9 www.praktykateoretyczna.pl

\title{
MICHAŁ KALECKI I PROBLEM RACJONALNEJ ALOKACJI ZASOBÓW W SOCJALIZMIE
}

\author{
DAMIAN WINCZEWSKI
}

\begin{abstract}
Abstrakt: Celem artykułu jest rekonstrukcja poglądów Michała Kaleckiego i jego zwolenników na temat racjonalnej kalkulacji i alokacji zasobów w gospodarce socjalistycznej, a także próba zestawienia tych poglądów z poglądami zwolenników zarówno kapitalizmu, jak i alternatywnych modeli socjalizmu. Pod tym kątem przeanalizowano artykuły polskiego ekonomisty dotyczące schematu tworzenia się cen w kapitalizmie i socjalizmie, roli klasy robotniczej oraz systemu bodźców i sposobu zarządzania gospodarką. W artykule omówiono też poglądy autorów, którzy bazując na pracach Kaleckiego, podjęli się polemiki z obiegową narracja wyjaśniająca porażkę realnego socjalizmu. Zarówno realny kapitalizm, jak i realny socjalizm zmagają się z problemami niedoskonałej informacji i miękkich budżetów, nie istnieje również doskonały model zarządzania gospodarką, w związku z tym nie są to bezpośrednie przyczyny niepowodzenia projektu socjalistycznego. Oprócz problemu innowacji i optymalnych nakładów inwestycyjnych z perspektywy kaleckiańskiej zasadniczym problemem socjalizmu wydaje się ustanowienie właściwych stosunków produkcji w marksistowskim sensie, rozumianych jako zdemokratyzowanie relacji pomiędzy klasą robotniczą a warstwą zarządzająca produkcja.
\end{abstract}

Słowa kluczowe: centralne planowanie, regulacja cen, inwestycje, alokacja zasobów. 


\section{Wstęp}

Współcześnie porażka gospodarki centralnie sterowanej wydaje się oczywista, co potwierdzają liczne opracowania na ten temat. Wiele z nich w warstwie teoretycznej bazuje na pogląach zwolenników austriackiej szkoły ekonomii, którzy z góry zakładali praktyczną niemożliwość racjonalnej alokacji zasobów w tym systemie. W związku z tym powszechny jest pogląd, że mechanizmu rynkowego nie można zastapić. Zgadzaja się z tym również nieliczni współcześni socjaliści, którzy dopuszczaja jedynie zdecentralizowany model socjalizmu, gdzie alokacja zasobów odbywałaby się głównie poprzez rynek.

Celem artykułu jest ustosunkowanie się do tych twierdzeń przez ukazanie ich w perspektywie poglądów Michała Kaleckiego i jego uczniów. Korzystając z bogatego dorobku tradycji kaleckiańskiej, chciałbym pokazać, że zarzuty zwolenników kapitalizmu wobec socjalizmu w wielu miejscach są niespójne. W kolejnej części tekstu omówię szereg propozycji Kaleckiego, które można przeciwstawić poglądowi o teoretycznej niemożliwości racjonalnej alokacji zasobów w gospodarce centralnie planowanej. Artykuł nie jest tylko historyczną rekonstrukcją - z perspektywy kaleckiańskiej można również krytycznie ocenić współczesne propozycje socjalizmu oddolnego. Problemy gospodarcze realnego socjalizmu w świetle niniejszego artykułu nie ograniczają się tylko do kwestii sztucznego systemu cen, niskiej innowacyjności czy złej polityki inwestycyjnej. Ważną rolę można przypisać też stosunkom produkcji, a dokładniej rzecz ujmując: sprzecznościom zachodzącym pomiędzy interesami ekonomicznymi klasy robotniczej i rządzącej nomenklatury partyjnej.

\section{Zarys problemowy debaty kalkulacyjnej}

Termin „debata kalkulacyjna” odnosi się do szeregu polemik dotyczących rachunku ekonomicznego w gospodarce centralnie planowanej, zapoczątkowanych esejem „Kalkulacja ekonomiczna w socjalizmie" napisanym w 1920 roku przez Ludwiga von Misesa. Głównymi postaciami tej debaty oprócz Misesa byli Friedrich von Hayek oraz Oskar Lange. Po stronie zwolenników socjalizmu głos zabierali, poza Langem, między innymi również Abba Lerner, Maurice Dobb czy Paul Sweezy i Paul Baran. W dyskusji brali udział także inni ekonomiści, jednakże z historycznego punktu widzenia największy wpływ na jej ciężar i ocenę miała wymiana zdań na linii Mises - Lange - Hayek. W związku z tym, że temat jest w literaturze ekonomicznej dość szeroko opisany, ograniczę się tylko do krótkiego podsumowania najważniejszych problemów i zazwyczaj przyjmowanych ocen tej dyskusji - by mieć punkt odniesienia przy rekonstrukcji poglądów Kaleckiego na kwestię racjonalnego gospodarowania w socjalizmie. 
1. Punktem wyjściowym dyskusji był problem dotyczący ustalania cen wobec braku mechanizmu rynkowego i własności prywatnej. Zdaniem Misesa istota poprawnej kalkulacji jest właściwa miara wartości, która pozwala ocenić, jakie dobro spośród wielu warto wyprodukować po jednej stronie i zakupić (spośród dóbr ekwiwalentnych użytkowo) po drugiej stronie. Austriacki ekonomista twierdził, że tę relację pozwala określić wartość wymienna, której miernikiem na rynku jest dobro wybrane - pieniądz (Mises 2012).

Zdaniem Misesa brak prywatnej własności czynników produkcji uniemożliwia ich obiektywną, rynkową wycenę. Wycena ta zostaje zastapiona przez subiektywną ocenę urzędników zajmujących się planowaniem gospodarczym. Badacz uważał również za niemożliwy rachunek ekonomiczny na podstawie teorii wartości opartej na pracy ze względu na tzw. problem transformacji, czyli kwestię tego, jak przekształcić społecznie niezbędną ilość czasu pracy w ceny rynkowe (Mises 2012, 42-44). W konkluzji doszedł do wniosku, że im większe będzie odchylenie od własności prywatnej, tym mniej racjonalne stanie się gospodarowanie produkcją (Lukawer 2005, 43).

Oskar Lange odrzucił teorię wartości opartą na pracy na rzecz teorii marginalistycznej, a następnie stwierdził, że ceny można ustalić, używając modelu równowagi ogólnej Walrasa i jego koncepcji aukcjonera.

Urząd planistyczny miałby przyjąć rolę swego rodzaju maszyny licytującej oraz metoda prób i błędów ustalić ceny na czynniki produkcji. Poprzez kolejne próby tworzenia nowych układów podaży i popytu osiagnnięte zostałyby ceny równowagi. Wyłonione w ten sposób ceny kalkulacyjne znalazłyby zastosowanie w rachunku ekonomicznym.

Austriaccy ekonomiści podnieśli zarzut dotyczący arbitralności okresu obowiązywania ustalonej ceny. Zarzuca się Langemu, że nie był precyzyjny, jeśli chodzi o częstotliwość zmian cen kalkulacyjnych. Według Hayeka, którego argument powtórzył i uszczegółowił Huerta de Soto $(2010,218-237)$, ceny - zmieniane rzadko - miałyby niska wartość jako sygnały przy procesie decyzyjnym dotyczącym alokacji zasobów. Jeżeli zaś częstotliwość zmian byłaby duża, wtedy ilość danych stałaby się tak olbrzymia, że paraliżowałaby cały proces decyzyjny. Gabriel Temkin (2008, 67) zarzucił natomiast, że kierownicy produkcji mogliby wpłynąć na kierunek zmiany cen wyznaczanych przez urząd planistyczny. Mogliby to robić za pomocą decyzji o zmianie rozmiarów zapasów, a co za tym idzie - także rozmiarów produkcji.

2. Kolejna kwestia dotyczyła przedsiębiorczych działań w socjalizmie i powiązanych z tym problemów z odpowiednimi bodźcami i motywacjami. Zdaniem zwolenników nieskrępowanej przedsiębiorczości w państwie socjalistycznym wynalazcy musieliby każdorazowo przekonywać urząd planistyczny o tym, że pomysł warto wdrożyć. Biurokrata pełniłby funkcję przedsiębiorcy i decydowałby o wdrożeniu innowacji czy wynalazków 
(Temkin 2008, 69). Sam Lange nie przejął się problematyką przedsiębiorczości, którą uznał za zagadnienie z dziedziny socjologii (1936/1973, 267).

Według ekonomistów austriackich problem jest dużo poważniejszy. Ich zdaniem przedsiębiorczość jako taka może przejawiać się tylko na wolnym rynku, w warunkach wzajemnej rywalizacji, gdzie głównymi bodźcami są zysk i chęć utrzymania się w rynkowej grze.

3. Za równie istotny uchodzi problem informacji. Sygnalizowany był już przez Vilfreda Pareta i Enrica Baronego. Zdaniem tego ostatniego rozwiązanie problemu kalkulacji sprowadzałoby się do rozwiązania systemu równań, których pomyślny wynik zapewniłby równowagę popytu i podaży, a co za tym idzie - maksymalizację dobrobytu. Formalnie rzecz biorąc, układ równań jednoczesnych opisujący wielkości gospodarcze w socjalizmie i kapitalizmie jest taki sam. W jednym i drugim przypadku daje takie same wyniki. Problem centralnego planisty polega więc na złożoności i trudności obliczeń (Hockuba i Brzeziński 2005, 5). Podstawowy ciężar tego problemu spoczywa na ekonomicznej zmienności technologicznych współczynników produkcji. Ustalenie tych współczynników tak, aby pozostawały w zgodzie $\mathrm{z}$ wymogiem minimalizacji kosztów produkcji, wymagałoby prowadzenia obliczeń na wielką skalę na poziomie przedsiębiorstw. Centralny planista z powodów technicznych nie dysponowałby więc informacją potrzebną do rozwiązania tych równań (Barone 1935, 587-588).

Podobnie uważał Lionel Robbins. Stwierdził, że można wyobrazić sobie rozwiązanie problemu kalkulacji, tworząc całe ciąi szeregów rachunków matematycznych. Wymagałoby to jednak ułożenia milionów równań mających za podstawę miliony danych statystycznych. Nim jednak wszystkie te równania zostałyby rozwiązane, dane uzyskane na ich podstawie stałyby się nieaktualne (Robbins 1934/2007, 151).

Argumentację tę popierał i rozbudował Hayek, który uważał, że po pierwsze system gospodarki planowanej ogranicza ludzką wolność (Hayek 1996), a po drugie - że istnieje zasób nieskodyfikowanej, niewyrażalnej matematycznej wiedzy, która jest wykorzystywana na wolnym rynku i nigdy nie będzie dostępna centralnemu planiście (Hayek 1949). Dla Langego problem informacji był zawsze tylko problemem technologicznym, ponieważ rynek stanowił dla niego wyłącznie specyficzny układ równań, do których rozwiązania potrzeba odpowiednio zaawansowanych komputerów (Lange 1973, 334).

Podstawę modelu Langego stanowiła metodologia neoklasyczna i to jej wykorzystanie zdaniem Dona Lavoie i Petera Boettkego, zwolenników szkoły austriackiej, było główną wadą tego projektu (Lavoie 1985; Lavoie i Boettke 2001; Boettke 2002). Podobne opinie wyrażali również lewicowi ekonomiści tacy jak Pat Devine i Fikret Adaman, a także Joseph Stiglitz (Adaman i Devine 1997; Stiglitz 1996). W Polsce krytyczna analiza modelu Langego zajmował się między innymi jego wybitny uczeń, Tadeusz Kowalik (1994, 
2004, 2005). Między innymi zwracał uwagę na krytykę modelu Langego przez innych socjalistów za niedostateczne uwzględnienie przez niego roli planowania - przy czym podkreślał, że sam Lange po wojnie odszedł od koncepcji „socjalizmu rynkowego” i skupił uwage na radzieckim modelu gospodarczym.

Ostatecznie upadek realnego socjalizmu dla większości ekonomistów stanowił praktyczny dowód przewagi mechanizmu rynkowego nad gospodarką planową, przez co dalsza dyskusja została de facto ucięta i zmarginalizowana.

\section{Czy informacja stanowi problem?}

Argumentacja Hayeka o tym, że istnieje niemożliwa do wyartykułowania i skodyfikowania wiedza niejawna (tacit knowledge), miała potężne oddziaływanie. $\mathrm{Na}$ argumenty austriackiego ekonomisty często powoływali się główni ideolodzy neoliberalizmu, uzasadniając w ten sposób tezę, że nie istnieje alternatywa dla proponowanych przez nich rozwiązań. Jednym $z$ wielkich admiratorów austriackiego ekonomisty był między innymi Milton Friedman, który powołując się na jego prace, położył fundamenty pod monetaryzm, myśl ekonomiczna, która odniosła znaczące sukcesy po załamaniu się keynesizmu po 1979 roku. Hayek twierdził, że nie tylko wszelkie próby planowania niweczą możliwość jej użycia, lecz także wolny rynek wytwarza spontaniczny porządek umożliwiający najefektywniejsze wykorzystanie tego typu wiedzy, do której zużytkowania nie byłaby zdolna żadna jednostka (Hayek 1945). Autor wyróżnił trzy typy gospodarki: 1) centralnie planowana, 2) konkurencyjną, która jego zdaniem jest agregatem planowych wyborów zatomizowanych jednostek, 3) formę pośrednia pomiędzy 1) i 2), czyli zmonopolizowana gospodarkę rynkowa. Jego zdaniem do najlepszego wykorzystania wiedzy niejawnej dochodzi w gospodarce typu 2), gdzie wiedza niejawna artykułuje się w konkurencyjnych cenach.

Pozycja Hayeka stała się jeszcze mocniejsza, gdy problem wiedzy niejawnej został spopularyzowany na polu filozofii nauki przez Michaela Polanyiego (1962, 1967). Kryzys i upadek gospodarek planowych doprowadził do tego, że koncepcja wiedzy niejawnej została zaakceptowana przez większość lewicowych i socjalistycznych ekonomistów jako dowód na wyższość mechanizmu rynkowego.

Od lat osiemdziesiątych XX wieku powstała pewna liczba modeli gospodarki socjalistycznej. Ich celem było zapewnienie pełnego zatrudnienia i sprawiedliwej redystrybucji dochodu narodowego, $z$ jednoczesnym poszanowaniem argumentacji Hayeka, której w zasadzie nikt nie podważał. Informacja stała się głównym problemem, który zwolennicy socjalizmu chcieli rozwiązać.

Nie będę w tym miejscu omawiał tych modeli gospodarki socjalistycznej, wyróżnię jedynie ich podstawowe wspólne cechy: 1) znaczące ograniczenie lub całkowite porzucenie 
centralnego planowania i zastapienie go aktywną polityką fiskalną państwa bądź (w najlepszym razie) planowaniem indykatywnym, 2) wprowadzenie alokacji czynników produkcji poprzez rynek, 3) całkowita decentralizacja i pozioma koordynacja firm, 4) wprowadzenie bodźców opartych na zysku, 5) wymóg twardego budżetu i dbania o rentowność zakładu. Przekonanie o decydującej roli rynku, na którym państwo powinno zachowywać się jak dbający o rentowność swojego interesu przedsiębiorca, zaczęło towarzyszyć również postulatom gospodarczym formułowanym przez partie lewicy głównego nurtu. Obrazuje to siłę, z jaką wizja rynku jako jedynego regulatora opanowała wszystkie liczące się obozy polityczne w wyniku krachu realnego socjalizmu. Od tej pory nawet jeżeli partie te posługiwały się retoryką prospołeczną, to nigdy nie podważały konieczności alokacji i regulacji rynkowej.

Krytykę tego rodzaju socjalizmów rynkowych podjęli nieliczni ortodoksyjni marksiści, tacy jak Ernest Mandel (1986, 1988), który przekonywał, że użycie mechanizmu rynkowego doprowadzi do powrotu wszystkich wad kapitalizmu, włącznie z niesprawiedliwym podziałem dóbr i redukcją zatrudnienia. Postulował on demokratyczne planowanie, w którym o alokacji i podziale dóbr mieliby decydować robotnicy głosujący na zjazdach lokalnych, regionalnych i krajowych. Mandel jednak nie stworzył żadnej spójnej propozycji, jego artykuły w mojej ocenie stanowiły raczej zbiór życzeń i postulatów.

W tej sytuacji jedynym obrońca centralnego planowania stał się szkocki informatyk Paul Cockshott (1993), który zaprojektował system planowania komputerowego oparty na tabelach przepływów międzygałęziowych. Jego koncepcja stała się jednak obiektem krytyki ze strony lewicowych ekonomistów (Hodgson 1999) właśnie za niedostateczne wzięcie pod uwagę argumentów Hayeka. Pokazuje to skalę sukcesu austriackiej szkoły ekonomii.

Wydaje się wobec tego, że ekonomiści będący zwolennikami socjalizmu i sprawiedliwości społecznej, skupiający się na budowie modeli, zupełnie zapomnieli o Kaleckim. Z perspektywy jego twórczości problematyka racjonalnej gospodarki socjalistycznej wygląda zupełnie inaczej. Zacznę od streszczenia argumentacji dwójki jego zwolenników, Roniego Demirbaga i Josepha Haleviego (2014), którzy podjęli się krytyki stanowiska Hayeka.

Po pierwsze stworzone przez austriackiego ekonomistę pojęcie spontanicznego porządku nie jest do końca jasne. Demirbag i Halevi twierdzą, że zdaniem wielu obserwatorów Hayek nie zbudował koherentnego kryterium demarkacji pomiędzy porządkiem a nieporządkiem. Na gruncie jego teorii spontanicznym porządkiem cechuje się nawet gospodarka rynkowa pograżona w stagnacji. Trudno też o empiryczną weryfikację tej teorii, ponieważ Hayek pojmował gospodarkę zarówno planowa, jak i rynkową dość skrajnie. Jaki rodzaj spontanicznego porządku wytworzyłby się w gospodarce mieszanej? 
Po drugie Hayek łączył wiedzę niejawną ze wszystkimi pozostałymi rodzajami wiedzy. Istnieją różne rodzaje wiedzy, wśród których wiedza niejawna jest tylko jednym, szczególnym przypadkiem. Wiele innych, w tym informacje potrzebne do bilansowania sektorów, da się bezproblemowo uzyskać, odczytać i scentralizować.

Autorzy sugerują również, że użycie wiedzy niejawnej nie stanowi w ogóle problemu w zdecentralizowanych modelach gospodarki planowej, do których nie odniósł się w swoich wywodach Hayek. Za przykład podają model planowania partycypacyjnego Fikreta Adamana i Pata Devine’a (1992, 2002). W modelu tym decyzje o alokacji zasobów miałyby podejmować specjalne komitety koordynacyjne, w których deliberowaliby reprezentanci załóg zakładów oraz reprezentacje konsumentów.

Nie mogę w tym miejscu zgodzić się z oceną Demirbaga i Haleviego, ponieważ ten i inne modele zdecentralizowanego, partycypacyjnego planowania były obiektem krytyki, w której zarzucano, że model zawodzi w wykorzystaniu wiedzy niejawnej. Geoffrey Hodgson (2005) zarzucał, że stopień partycypacji w nim jest zbyt wysoki, ponieważ uczestnicy deliberacji będą mieli zbyt wiele decyzji do podjęcia, a niekończące się debaty o tym, jakie dobra i w jakiej ilości mają być produkowane, wręcz sparaliżują proces pozyskiwania informacji.

Demirbag i Halevi postanowili odnieść się również do argumentu Hayeka mówiącego, że transakcje zawierane przez uczestników wymiany rynkowej powinny być pozbawione przymusu, ponieważ jest to zamach na ludzką wolność. Stwierdzili, że proponowana przez austriackiego ekonomistę definicja przymusu jest dwuznaczna. Hayek twierdził, że gdyby człowiek kontrolujący zapas wody na pustyni, wykorzystując swoja monopolistyczną pozycję, żądał „zbyt wysokiej ceny”, to byłby to akt przymusu. Nie zdefiniował jednak, jaka cena jest zbyt wysoka. Uważał, że cena powinna być konkurencyjna. Tylko jak zdefiniować konkurencyjną cenę przy braku konkurencji?

Poza tym - żeby gospodarkę rynkową uznać za pozbawioną przymusu, należałoby znieść niesymetryczną relacje pomiędzy pracownikami a przedsiębiorcami na rynku pracy. Wymagałoby to zatem pełnego zatrudnienia, a co za tym idzie - równowagi rynkowej.

Argumenty na rzecz supremacji kapitalizmu w tym kontekście nie są więc przekonujące. Hayek posługiwał się niejasnymi pojęciami wiedzy i przymusu. Do tego nie jest wcale oczywiste, że każdy mechanizm koordynacji powoduje gorsze wykorzystanie informacji i prowadzi do większego przymusu niż wolnorynkowy kapitalizm pozbawiony pełnego zatrudnienia.

Paul Ayerbach i Dmitris Sotiropoulos zauważyli, że Hayek sam podświadomie musiał zdawać sobie sprawę ze słabości swoich założeń. Bronił wyidealizowanego obrazu gospodarki wolnorynkowej, ponieważ zdaniem autorów miał świadomość, że każdy rodzaj 
interwencji stanowi cios dla logiki kapitalistycznej reprodukcji opartej właśnie na przymusie i wyzysku (2014).

Innymi słowy, autorzy wyrazili znany wśród radykalnej lewicy pogląd, że Hayek w rzeczywistości nieświadomie bronił kapitalistycznego wyzysku. Trzeba przyznać, że austriacki ekonomista poniekąd słusznie obawiał się mechanizmu przymusu państwowego, choć również nigdy nie zadał sobie trudu przeanalizowania proponowanej przez wielu socjalistów teoretycznych koncepcji demokracji robotniczej.

\section{Rzeczywista funkcja cen według Kaleckiego}

Przez lata zwolennicy socjalizmu i wolnego rynku spierali się, jak powinny być kształtowane ceny, aby dostarczały rzetelnej informacji i umożliwiły poprawny rachunek ekonomiczny. Demirbag i Halevi starali się pokazać, że przewaga konkurencyjnych cen rynkowych nie jest oczywista.

Dla samego Kaleckiego sprawa była jeszcze prostsza i trudno się dziwić, że nigdy nie zadał sobie trudu podjęcia polemiki z wolnorynkowymi autorami. Bezpośrednio do tej kwestii odniósł się tylko raz, zabierając głos odnośnie referatu Langego „Praktyka planowania gospodarczego a optymalna alokacja zasobów” na konferencji w Waszyngtonie w 1947 roku. Kalecki stwierdził, że cała ta dyskusja jest bezprzedmiotowa, ponieważ porównuje się rzeczywiście istniejący socjalizm z doskonale konkurencyjną gospodarką kapitalistyczną, która nigdy nie istniała. Odniósł się do sformułowanego przez Langego problemu zrównywania cen z kosztami krańcowymi w gospodarce socjalistycznej:

\footnotetext{
(...) jest zupełnie jasne, że w gospodarce kapitalistycznej ceny nie są wcale wyznaczane w taki sposób, ale rządzi nimi przeciętny koszt zmienny i coś w rodzaju stopnia monopolizacji albo zasady kosztu pełnego (full cost). Czy jednak zapewnia to optymalną alokację środków? Dlaczego mielibyśmy ubolewać, że w gospodarce planowej nie zachodzi ścisła równość między cenami a kosztami krańcowymi, skoro taka zasada nigdy nie była realizowana? $(1947 / 1982,384)$.
}

Jak widać, czynione wobec gospodarki socjalistycznej zarzuty dotyczące tego, że ceny nie stanowią obiektywnego odzwierciedlenia kosztów krańcowych, są zdaniem autora Teorii dynamiki gospodarczej bezzasadne. Interesowała go nie podręcznikowa, lecz realna rzeczywistość gospodarcza, a w tej doskonała informacja i optymalna alokacja zasobów nie istnieja.

Kalecki uważał, że kapitalizm przez całą swoją historię opierał się na konkurencji niedoskonałej. W jej ramach mamy do czynienia z krótkookresowymi zmianami cen. Ze względu na determinanty tych zmian można je podzielić na dwie grupy: 1) ceny gotowych 
produktów, określone zmianami przeciętnych kosztów produkcji, 2) surowce i płody rolne, których cena przy nieelastycznej podaży rośnie wraz z wzrostem popytu (1954/1980, 216). Istotę różnicy pomiędzy powyższymi grupami cen ujął Kazimierz Laski w sposób następujący - zwiększenie produkcji surowców (np. mineralnych) często wymaga odkrycia nowych złóż, a także często długotrwałych inwestycji, natomiast „podaż wyrobów gotowych jest elastyczna nawet w krótkim czasie" (Laski, 2009, 13-14). Zatem w powyższym ujęciu w gospodarce kapitalistycznej koszty produkcji, jak również zachowanie się konkurentów na rynku mają bardzo ważny wpływ na maksymalizację zysku.

Poglądy na temat wolnego rynku polski ekonomista miał takie jak większość marksistów: nawet gdyby znieść wszelki nadzór nad przedsiębiorstwami, wystapiłaby wtedy naturalna tendencja do koncentracji i centralizacji kapitału. Wówczas przedsiębiorstwa osiagające najlepsze w tym wymiarze wyniki przekształciłyby się w monopole, oligopole i kartele, które między sobą ustalałyby politykę cenową (Kalecki 1958/1982, 156). Nie oznacza to jednak, że cała gospodarka zostałaby zdominowana przez kilka wielkich korporacji, jak sądził Marks. Claudio Sardoni (2011, 119) trafnie zauważył, że analiza polskiego ekonomisty była bardziej realistyczna, ponieważ Kalecki zakładał, że monopolizacji gospodarki będzie towarzyszyć liczna obecność wielu małych przedsiębiorstw.

W praktyce dojrzałego kapitalizmu - zdaniem Kaleckiego - ceny w większości przypadków nie są wyznaczane przez popyt na wytwarzane dobra, ale przez koszta produkcji, których cena z kolei określana jest głównie przez „czynniki monopolistyczne i półmonopolistyczne" (1958a/1982, 152).

Przedsiębiorstwo kapitalistyczne, ustalając cenę danego produktu, bierze zatem pod uwagę jego przeciętny koszt zmienny oraz ceny ustalone przez pozostałe przedsiębiorstwa na ten produkt. Upewnia się przy tym, że cena nie będzie ani zbyt wysoka, ani zbyt niska, ponieważ obniżyłoby to zyski $(1954 / 1980,216)$. Relację tę wyraża równanie:

$$
p=m u+n p
$$

- gdzie $p$ oznacza cenę, $u$ to koszty zmienne, $p$ to ważona średnia cena wszystkich przedsiębiorstw, natomiast $m$ i $n$ to wskaźniki dodatnie. Tak wygląda pólmonopolistyczne kształtowanie się ceny. Gdy czynniki $m$ i $n$ są zmienne, ogólne kształtowanie się cen w przemyśle wyraża następujące równanie:

$$
p=\frac{m}{1-n} u
$$

- gdzie $m$ i $n$ oznaczają średnie ważone współczynników $m$ i $n$ (1954/1980, 220). W ten sposób ogólnie kształtują się ceny w zmonopolizowanym przemyśle. 
W ekonomii postkeynesowskiej powstało wiele rekonstrukcji, interpretacji i rozwinięć koncepcji stopnia monopolizacji (Arestis 1996; Reynolds 1996; Chilosi 2004; Michell 2014; Bhaduri 2015), nie będę jednak w tym miejscu ich analizowal, ponieważ nie wpływa to na główną linię prezentowanego tu argumentu.

Kalecki - posługując się marksowskimi schematami reprodukcji - stworzył model zamkniętej gospodarki bez udziału państwa, gdzie cały dochód dzieli się na konsumpcję I oraz inwestycje C. Dział I produkowałby dobra inwestycyjne, a dział II - dobra konsumpcyjne. Dochód narodowy jest sumą przyrostu produkcji obu działów, wyrażoną w formule: $\Delta \mathrm{Y}=\Delta \mathrm{I}+\Delta \mathrm{C}$, gdzie $\Delta \mathrm{I}$ to przyrost produkcji brutto w dziale $\mathrm{I}, \Delta \mathrm{C}$ to przyrost produkcji w dziale II. Jednocześnie zdaniem Kaleckiego występuje pomiędzy nimi pozytywna korelacja - gdy zmniejszają się inwestycje kapitalistów, zmniejsza się także spożycie klasy pracującej (1958a/1982, 154). Pełne wykorzystanie potencjału produkcyjnego w dziale II zależne jest od wykorzystania potencjału działu I, czyli wzrost konsumpcji zależy od wzrostu inwestycji. W kapitalizmie przeważnie zachodzi zależność $\mathrm{I}<\mathrm{I}_{0}$. To znaczy, że w tym systemie rozmiar inwestycji zazwyczaj jest mniejszy od poziomu, który umożliwiałby maksymalne wykorzystanie sił wytwórczych w dziale II. Skutkami niewykorzystania pełni zdolności produkcyjnych $\mathrm{w}$ tym dziale sa niepełne zatrudnienie i mniejsza ilość dóbr konsumpcyjnych.

Negatywne skutki niedostatecznego wolumenu inwestycji prywatnych moga być niwelowane przez interwencję państwa lub wskutek walki klas, a dokładniej - przez działania związków zawodowych dążących do wzrostu płac. Gdy marża zysku przedsiębiorstwa jest wysoka, silne związki zawodowe śmielej zabiegaja o podwyżki dla pracowników, ponieważ są świadome, że nieco mniejsze zyski nie wpłyną negatywnie na rentowność firmy. Gdyby przedsiębiorstwo w celu ochrony swojej marży znowu podniosło ceny, związki nalegałyby na kolejną podwyżkę (1954/1980, 223). Przy silnej pozycji związków przedsiębiorstwa nie moga więc trwale zwiększyć zysków bez zwiększenia kosztów. Jeżeli jednak pozycja klasy robotniczej byłaby słaba, przedsiębiorstwa mogłyby podwyższać marże zysku, nie ponosząc kosztów płacowych, a zatem pomniejszałyby konsumpcję klasy robotniczej (1971a/1980, 133).

Z powyższego wynika, że ceny nie tylko dostarczają informacji rynkowej, ale pełnią również funkcję redystrybucyjną - ich wysoki poziom przy braku interwencji związków zawodowych zwiększa przepływ dochodu narodowego do kapitalistów, a zmniejsza udział klasy robotniczej w jego podziale. Ceny nie sa więc agregatem planowych decyzji niezależnych jednostek, ale stanowią w nieoczywisty sposób efekt walki klasowej o podział dochodu narodowego.

Kalecki co prawda twierdził, że walka klasowa jest jednym z kilku czynników wpływających na ten podział, jednak - by być konsekwentnym - trzeba przyjąć szersza, 
historiozoficzną perspektywę, zgodnie z którą koncentracja kapitału oraz tendencje przedsiębiorstw do zmowy są rezultatem walk klasowych wygranych przez klasę kapitalistyczną w przeszłości - także w gronie własnej klasy wielkie korporacje, wykorzystując własna pozycję, moga „wyzyskiwać” mniejsze przedsiębiorstwa i zwiększyć ich kosztem swój udział w dochodzie narodowym.

Fernando Rugitsky (2013) dostrzegł, że przedsiębiorcy w kaleckiańskim modelu kapitalizmu nie są ograniczeni tylko do standardowych metod wywierania presji klasowej, takich jak podwyżki cen, zwolnienia, lokauty itd. Biorąc pod uwagę polityczne cykle koniunkturalne (Kalecki 1943/1979), przedsiębiorcy potrafią wywierać również znaczący wpływ na interwencję państwa i - jak twierdzi Rugitsky - moga wymusić na państwie korzystniejszy dla siebie, a gorszy dla robotników, podział dochodu narodowego, np. poprzez preferencyjną względem przedsiębiorstw politykę fiskalną.

Marksistowska koncepcja walki klas jest kompatybilna ze stanowiskiem Kaleckiego. Stanowi też jeden $z$ kluczowych aspektów ustalania cen i podziału dochodu narodowego w realnie istniejącym kapitalizmie. Walka klas ma też wpływ na alokację zasobów. Przedsiębiorcy kapitalistyczni będą przecież chętniej inwestować i produkować w regionach i krajach, gdzie pozycja klasy robotniczej jest słaba, dzięki czemu marża zysku będzie większa. W tym kontekście nie może dziwić zatem pesymistyczny stosunek polskiego ekonomisty do tego systemu i opowiedzenie się za socjalizmem, gdzie rząd teoretycznie powinien reprezentować interes całego społeczeństwa.

W socjalizmie ceny również mają charakter redystrybucyjny, dzięki centralnemu sterowaniu, jednak gospodarka teoretycznie powinna uniknąc negatywnych efektów monopolizacji. Polski ekonomista dowodził, że w sferze gospodarczej występuje poważna różnica pomiędzy kapitalizmem a socjalizmem - gospodarka kapitalistyczna przeważnie pracuje przy niepełnym wykorzystaniu sił wytwórczych, gospodarka socjalistyczna natomiast posiada tendencję do ich nadmiernego wykorzystywania - w socjalizmie co do zasady cała siła robocza i wszystkie urządzenia produkcyjne mają być w pełnym użyciu, jednakże w praktyce występowała tendencja polegająca na tym, że rozwój sił wytwórczych nie nadążał za rosnącym zagregowanym popytem na nie, generując braki w zaopatrzeniu (Kołodko i Mahon 1987). W związku z tym Kalecki doszedł do wniosku, że gdy w gospodarce socjalistycznej poziom inwestycji się zmniejsza, następuje wzrost konsumpcji. Dynamika konsumpcji została przez niego opisana równaniem: $K=D-I-n \Delta D$, gdzie $\mathrm{K}$ to konsumpcja, $\mathrm{D}$ to dochód narodowy, I to inwestycje, $n \Delta D$ to przyrost dochodu narodowego w danym roku. Po podzieleniu całego równania przez D okazuje się, że udział konsumpcji w dochodzie narodowym zmniejsza się wraz ze zwiększeniem udziału inwestycji i tempem przyrostu dochodu narodowego $(1959 / 1982,174)$. 
W socjalizmie celem nie jest utrzymanie równowagi pomiędzy ceną a przeciętnym kosztem produkcji, tak jak w przypadku kapitalistycznych przedsiębiorstw, które dążą do maksymalizacji marży zysku. W związku z podażowym charakterem gospodarki socjalistycznej - tzn. gospodarki, w której w praktyce wszystkie wyprodukowane dobra znajdują nabywcę - za ważną funkcję cen można uznać regulację dostępu do nich.

Kalecki zauważył jednakże, że w zamkniętej gospodarce socjalistycznej dochodziłoby do marnotrawstwa surowców podstawowych, ponieważ ich niedobór nie znajdowałby odzwierciedlenia w cenach. Dlatego sugerował, że w realnym socjalizmie, mającym kontakt z międzynarodowym rynkiem kapitalistycznym, ceny na surowce podstawowe powinno się ustalać w relacji do cen światowych $(1957 / 1982,132)$.

Zorientowany czytelnik mógłby zarzucić Kaleckiemu, że ten de facto przyznał rację Misesowi. Przedstawiciel szkoły austriackiej uważał kalkulację w socjalizmie za możliwą wówczas, gdy kraj socjalistyczny znajdowałby się w otoczeniu gospodarek kapitalistycznych. Wtedy socjalistyczni planiści mieliby dostęp do informacji rynkowych, na bazie których mogliby ustalić ceny (Mises 1951, 118-119). Na pierwszy rzut oka wydaje się więc, że obaj ekonomiści byli zgodni co do ograniczeń socjalizmu. Sprawa jest jednak bardziej skomplikowana.

Po pierwsze Mises uparcie trzymał się założeń Eugena von Böhm-Bawerka (1898) bazujących na literalnym odczytaniu dzieł Marksa. W związku z tym sądził, że rachunek ekonomiczny oparty byłby na kalkulacji społecznie niezbędnego czasu pracy (Mises 1951, 133-134). Nieposiadający systemu cenowego „prawdziwy” socjalizm dążyłby do bycia autarkią i minimalizowałby import (Mises 1951, 222-223), ponieważ zalew tanich produktów załamałby krajowa produkcję. Państwo socjalistyczne nie mogłoby posiadać również środków produkcji za granica, ponieważ planiści byliby skupieni wyłącznie na produkcji na rynek wewnętrzny (Mises 1951, 235).

W związku z tym Mises uważał radziecką gospodarkę za „fałszywy” socjalizm, to znaczy socjalizm „municypalny”, ponieważ według niego Związek Radziecki nie podążał ściśle za wskazówkami Marksa i Engelsa, tylko wytworzył system cenowy i dostosowywał swoją politykę gospodarczą do międzynarodowego, kapitalistycznego otoczenia, podobnie jak samorządy prowadzą politykę socjalną uzależnioną od zewnętrznych warunków gospodarczych. Twierdził, że socjalizm municypalny „,nie reprezentuje żadnego szczególnego ideału ekonomicznego" (Mises 1951, 249). Zatem gospodarka radziecka była swoistym wypaczeniem ideałów socjalistycznych.

Z tej perspektywy Kalecki był daleki od idealizacji Misesa. Wiążąc ceny krajowe z cenami światowymi, chciał dostarczyć bodźców do oszczędzania surowców. Pozostanie przy cenach krajowych spowodowałoby bowiem rozrzutność - jeżeli w obiegu wewnętrznym wartość towaru $\mathrm{A}=$ wartość towaru $\mathrm{B}$, a w obrotach zagranicznych $\mathrm{A}=3 \times \mathrm{B}$, to bodźce 
do oszczędzania będą takie same dla obu towarów, mimo że na rynku zagranicznym towar A jest warty trzykrotnie więcej $(1957 / 1982,132)$.

Celem, który przyświecał polskiemu ekonomiście, było wyrównanie bilansu płatniczego. Obawiał się on wzrostu zadłużenia zagranicznego, ponieważ trafnie przewidywał negatywny wpływ uzależnienia gospodarki socjalistycznej od dewiz krajów kapitalistycznych znaczący wzrost zadłużenia zagranicznego był obserwowalny zarówno w krajach zależnych od ZSRR, jak PRL (Krawczyk 1990) czy Rumunia (Ban 2012), jak i w niezależnych, np. w Jugosławii (Dyker 2011). Towary będące przedmiotem handlu zagranicznego określił mianem surowców dewizowych i zaproponował metodę obliczania wydatków na ich produkcję, którą wyraża następujące równanie:

$$
D=\frac{W x S}{1-\operatorname{ax} 100}
$$

- gdzie D to suma wydatków dewizowych, s to wskaźnik przyrostu importu bądź redukcji eksportu wyrażony w dolarach, W to wydatki dewizowe równe płacy, $(1-$ a) $\times 100$ to koszta przyrostu masy towarowej na 100 złotych $(1957 / 1982,134)$. Oszczędności wynikające z tej metody kalkulacji umożliwiłyby zwiększenie zysków z eksportu. Kalecki postulował, żeby zysk z eksportu towarów o wartości w obcej walucie był co najmniej równy wydatkom dewizowym. Proponował także ustalenie kursu maksymalnego na surowce dewizowe w stosunku $[(1-a) \times 100] / s$. W ostatecznym rozrachunku kurs maksymalny mógł doprowadzić do wzrostu cen surowców podstawowych na rynku krajowym, jednocześnie jego przyjęcie miało prowadzić również do: 1) maksymalizacji bodźców do oszczędności surowców, 2) zwiększenia kontroli nad opłacalnością transakcji eksportowych (1957/1982, 135-136).

Polski ekonomista bynajmniej nie był bezkrytyczny wobec idei centralistycznego tworzenia cen na surowce podstawowe. W referacie „O cenach surowców podstawowych” wskazuje na możliwe trudności związane z oceną efektywności inwestycji w surowce biorące udział w handlu międzynarodowym oraz na to, że przy ustalaniu cen trzeba liczyć się z wpływem bieżących problemów z eksportem i importem produktów (1958b/1982, 151). Poza tym liczył się z tym, że państwowe przedsiębiorstwa w gospodarce centralnie planowanej mogą być skłonne do manipulacji cenami produktów gotowych w celu zwiększenia swoich zysków (1958a/1982, 157).

Dla Misesa ustalenie cen odzwierciedlających relacje na rynkach światowych miało charakter esencjalny i umożliwić miało „obiektywną” wycenę towarów na rynku. Rozwiązanie Kaleckiego miało natomiast charakter praktyczny i instrumentalny: krajowe ceny na surowce podstawowe mają odzwierciadlać ceny światowe jedynie w przybliżeniu (1958b/1982, 147 149). Ceny krajowe więc nie mają być wrażliwe na wszelkie wahania cen światowych, a zatem ich celem nie jest obiektywna, rynkowa wycena. 
Pomimo podobnych ustaleń Kalecki nie potwierdzał przypuszczeń Misesa, że otwarta gospodarka socjalistyczna musi się załamać pod wpływem konkurencji i importu z krajów kapitalistycznych, ponieważ nie będzie w stanie przeciwstawić im własnych produktów. Polski ekonomista sądził, że ustanowienie cen na surowce w relacji do cen na rynku światowym może dostarczyć bodźców do produkcji eksportowej, co dawałoby szansę na uzyskanie nadwyżki w bilansie płatniczym. Jednakże w dalszym ciagu kraje socjalistyczne nie mogłyby kontrolować opłacalności handlu międzynarodowego, ponieważ nie posiadały informacji na temat kosztów jednostkowych, a także nie mogły nad nimi panować.

Kalecki był sceptyczny wobec ustanowienia wspólnej bazy cen krajów uznawanych za socjalistyczne (czyli w konkretnym historycznym przypadku krajów RWPG). Powstanie takowej bazy uzależniał od wprowadzenia ceł, które uzależniałyby ją od cen światowych (1962a/1982, 158-159) w celu zachowania bodźców do prowadzenia opłacalnej produkcji eksportowej. Jak zauważył Jerzy Osiatyński, obawy Kaleckiego wynikały również z tego powodu, że ustalenie wspólnych cen wymagałoby ujednolicenia metod kalkulacji kosztów produkcji we wszystkich krajach, co mogłoby się okazać zbyt trudne (1982, 387).

Kalecki na początku lat sześćdziesiątych XX wieku stał na czele zespołu powołanego przez przewodniczącego Komisji Planowania. Zespół ten ustalił, że podstawą rozliczeń na rynku krajowym powinny być ceny fabryczne, tj. określane przeciętnymi kosztami produkcji i powiększone o odpowiednie narzuty w celu stymulowania produkcji (1957c/1982, 122). Różnice pomiędzy cenami fabrycznymi a cenami zbytu miały być regulowane podatkiem obrotowym w trakcie trwania planu (1964a/1982, 400-401).

Metodologia ta stanowiła wyraźny postęp w stosunku do rozwiązań z modelu Langego, ponieważ ceny nie byłyby ustalane statycznie i dopasowywane za pomoca prób i błędów, tylko na bieżąco regulowane poprzez politykę fiskalną.

\section{Przeceniane modele}

Wśród uczniów Kaleckiego nie ma zgody co do jego wizji gospodarki socjalistycznej. Domenico Mario Nuti (1986) twierdził, że polski ekonomista stworzył spójny i kompleksowy model gospodarki socjalistycznej, który charakteryzował się powiązaniem cen z inwestycjami, regulacjami ilościowymi, wskaźnikami wydajności dla firm oraz istotną rolą kontroli robotniczej. Zdaniem Jana Toporowskiego (1996) natomiast prace Kaleckiego stworzyły nie kompleksowy system, lecz szereg studiów poświęconych konkretnym problemom funkcjonowania gospodarki socjalistycznej. Toporowski podobnie jak Nuti zauważył, że Kalecki starał się stworzyć optymalną strukturę konsumpcji, której zadaniem było dopasowanie planowanych inwestycji do potrzeb ludności, w odróżnieniu jednak od 
włoskiego ekonomisty Toporowski uważał, że projekt ten był daleki od kompleksowości, podobnie jak studia Kaleckiego nad rynkiem pracy w socjalizmie, które były jeszcze mniej zaawansowane. Celem Kaleckiego bowiem nie było stworzenie ogólnej teorii socjalizmu, ale raczej poszukiwanie praktycznych rozwiązań (Toporowski 1996), które np. pogodziłyby planowanie z demokratyczną kontrolą robotniczą (Toporowski 2004). Wynikać to miało z jego niestandardowej jak na ekonomistę metodologii, która polegała nie na analizowaniu teorii, lecz na empirycznej obserwacji rzeczywistości i wyciaganiu z niej indukcyjnych wniosków (Toporowski 1991).

W mojej ocenie Toporowski miał zdecydowanie więcej racji niż Nuti. Sam Kalecki w różnych okresach swojej działalności proponował różniące się w szczegółach rozwiązania ekonomiczne. W sferze doktrynalnej był zwolennikiem demokracji robotniczej, czemu dał wyraz w słynnym artykule „Warunki powstania demokratycznej gospodarki planowej” (1942/1982, 76). Nie uważał jednak jej za główny wyznacznik sukcesu gospodarczego. Jego propozycje wymagały w równym stopniu wysokiej jakości urzędników zajmujących się planowaniem.

Wydaje się, że tworzenie modeli było zgubne dla takich ekonomistów jak Lange, który trzymał się ściśle teorii, tak jak i dla ekonomistów radzieckich uzależnionych z kolei od wytycznych o charakterze ideologicznym. Nie znaczy to jednak, by Kalecki popierał eklektyzm polegający na próbach łączenia socjalizmu z mechanizmem rynkowym, w którym nadzieje widzieli współcześni mu ekonomiści i w którym nadzieje widzą dzisiaj współcześni socjaliści rynkowi. Nie popierał też radykalnej decentralizacji polegającej na oddaniu robotnikom pełnej kontroli nad zatrudnieniem i produkcja.

Współcześnie taką koncepcję propaguje np. Bruno Jossa (2014), który popiera tworzenie spółdzielni pracowniczych finansowanych z kredytów bankowych. Jego zdaniem pracownicy, wykorzystujący kapitał dla rozwoju własnej firmy, zmieniając w ten sposób stosunek sił między pracą a kapitałem na korzyść pracy. W ten sposób tworzenie spółdzielni oznaczałoby w praktyce zawiązywanie socjalistycznych relacji społecznych. Adaman i Devine (2001, 2006) uważali natomiast, że robotnicy mogliby ujarzmić mechanizm rynkowy, gdyby dogadali się z konsumentami w specjalnych komitetach, gdzie decydowaliby wspólnie, co produkować. Michael Albert i Robert Hehnel (1992, 2002) poszli o krok dalej. Doszli do wniosku, że społeczeństwa mogłyby oddolnie porozumiewać się w sprawie zaspokojenia konsumpcji z pominięciem rynku i władz centralnych.

Z perspektywy kaleckiańskiej tego rodzaju modele wydają się zbyt skoncentrowane na doktrynalnych pryncypiach, to znaczy nie odnoszą się do współczesnych problemów funkcjonowania gospodarki (np. informatyzacji, usieciowienia gospodarki, roli wiedzy). Relacje pomiędzy sektorem publicznym a rynkiem Kalecki pojmował pragmatycznie, bazując na aktualnych problemach gospodarki, którymi w danej chwili się zajmował. 
Tuż po wojnie w obliczu trudnej sytuacji aprowizacyjnej dopuszczal istnienie swobodnej wymiany i rynkowych cen $w$ handlu detalicznym. Uważał bowiem, że przedsiębiorstwa państwowe, umiejętnie regulując ceny komercyjne na produkty, mogłyby zarabiać na kontaktach z sektorem prywatnym i zwiększać w ten sposób wpływy do budżetu. Państwo miałoby wtedy więcej środków na subsydiowanie zubożałych warstw społeczeństwa (1946a/1982, 30-31). Jednocześnie jednak popierał interwencję państwową i administracyjne racjonowanie w przypadkach, gdyby było to potrzebne, np. jeśli pośrednicy chcieliby przerzucić koszty podwyżek cen komercyjnych na konsumentów (1946a/1982, 28-29).

Ważniejsze było jednak nie tyle odpowiednie dopasowanie państwa do rynku, ile uzdrowienie jego finansów poprzez ich centralizację i wprowadzenie jednolitego systemu racjonowania. Za równie istotne uznawał Kalecki zracjonalizowanie obiegu pieniężnego i wydatków budżetowych (1946b/1982, 1946c/1982). Stworzenie funkcjonalnej polityki fiskalnej państwa było zatem w ujęciu Kaleckiego sprawą bardziej podstawowa niż modelowanie jego poszczególnych sektorów.

Decentralizacja gospodarki socjalistycznej w studiach Kaleckiego również stanowiła zagadnienie nie tyle systemowe, ile funkcjonalne. Nie miała być nastawiona na zmiany w kierunku rynkowym, które dla wybranych jego lewicowych zwolenników oznaczały wolność od przymusu państwowego i demokratyzację. Według Kaleckiego liberalizacja gospodarki powinna mieć ograniczony zasięg, to znaczy autonomia zakładów nie mogła zakłócić ustalonego odgórnie planu rozwoju gospodarki narodowej.

Twórca Próby teorii koniunktury popierał liberalizacje drobnego przemysłu pod postacią spółdzielni i niewielkich zakładów państwowych. Miało to po pierwsze uwolnić je od uciążliwej kontroli biurokratycznej i jej nadużyć, a po drugie zapobiegać marnotrawstwu - państwo dostarczałoby materiały po takich cenach, żeby nie opłacało się ich sprzedawać na wolnym rynku, spółdzielnie musiałyby produkować też wtedy towary konkurencyjne wobec państwowych i korzystać z odpadów. Państwo w pewnych wypadkach mogłoby subsydiować spółdzielnie tańszymi materiałami, ale zasadniczo spółdzielnie miałyby finansować się same i współpracować między sobą, tworząc regionalne centra zaopatrzenia (1956a/1982, 83). Podobną politykę Kalecki zalecał stosować wobec zakładów rzemieślniczych. Dodawał, że rzemieślników można motywować dodatkowo ulgami podatkowymi i pozwalać im zatrudniać niewielką liczbę pracowników najemnych (1956a/1985, 85).

Co do drobnych zakładów państwowych - zalecal, aby finansować je z państwowych funduszy, kontrolę nad nimi zaś pozostawiał radom wojewódzkim. Proponował też wprowadzenie w całym sektorze państwowym systemu następujących bodźców materialnych: 1) mniejsze premie dla kierownictwa, ale większa stała płaca, żeby kierownikom zależało na utrzymaniu posad, 2) premie pieniężne powinny być uzależnione od stopnia wykonania planu (im większy stopień, tym większa premia), 3) premie powinny 
być uzależnione od oszczędności, 4) normy planu powinny rosnąć w mniejszym stopniu niż wydajność pracy, 5) jednocześnie udział załogi w zyskach należy rozłożyć na kilka lat, aby pracownicy myśleli długoterminowo (1956b/1982, 87-91).

Bodźce miały być powiązane $z$ inwestycjami w następujący sposób: 1) inwestycje centralne powinny być oparte na bezzwrotnym kredycie, który byłby oprocentowany, przedsiębiorstwa spłacałyby odsetki za amortyzację, 2) inwestycje zdecentralizowane miały być kredytowane na wyższy procent, co miało odstraszać od nierentownych inwestycji $(1957 \mathrm{c} / 1982,123)$.

Poza tym fundusz płac zakładów miał być uzależniony od produkcji czystej (cena fabryczna - faktyczny koszt produkcji), tzn. jego wzrost zależałby od wzrostu tego rodzaju produkcji (1957c/1982, 118-119). W celu zapobieżenia redukcji zatrudnienia całość funduszu miała być wykorzystywana niezależnie od liczby zatrudnionych. Jeżeli fundusz płac zostałby przekroczony, to różnica między wypłatami a wartością funduszu zostałaby odliczona od następnej wpłaty na fundusz zakładowy $(1957 c / 1982,124)$.

Kalecki - mimo wielu pomysłowych wskazówek - nie przeceniał roli bodźców. W jego ocenie decydujące znaczenie dla rozwoju gospodarki i jednocześnie polepszenia jakości życia miały takie czynniki jak tempo wzrostu i bilans handlu zagranicznego. Liberalizacja przemysłu nie miała na celu powiększania zysków, ale raczej oszczędność, ograniczenie biurokracji i marnotrawstwa.

Rola rad robotniczych w tak zdecentralizowanych zakładach było: 1) zapobieganie nadużyciom kierownictwa, 2) przeciwdziałanie tendencjom do centralizacji i biurokratyzacji, 3) pobudzanie oddolnej inicjatywy. Polski ekonomista sprzeciwiał się tendencjom syndykalistycznym, to znaczy nie chciał, aby zakłady samodzielnie ustalały ceny - w wyniku zmowy mogłyby być podwyższane, aby zapewnić większe zyski, co odbiłoby się negatywnie na produkcji. Jednocześnie spowodowałoby to podrożenie materiałów dostarczanych przez pośredników (1956c/1982, 93-106).

Kalecki dostrzegał to, czego nie dostrzegają współcześni socjaliści rynkowi i syndykaliści. Niezależnie bowiem od stopnia autonomii robotniczej groźba biurokratyzacji zawsze będzie istnieć. Dla polskiego ekonomisty ważną rolę odgrywał dług zagraniczny, którego zbyt duże rozmiary mogły wpływać negatywnie na gospodarkę niezależnie od takich czynników jak wpływ pracowników na funkcjonowanie zakładów. Zbyt niezależne zakłady moga także zwalniać pracowników, aby zwiększyć wypłaty pozostałych. Zakłady kontrolowane przez robotników nie istnieją również w próżni - sektory są ze sobą powiązane, np. przetwórczy z rolniczym (1957a/1982, 106). Oprócz tego sądzil, że pozbawione kontroli zakłady zaczną zachowywać się tak jak w kapitalizmie - tzn. wystąpi tendencja do monopolizacji i centralizacji. 
Obawy autora zostały potwierdzone w badaniach Tei Petrin i Alesa Vahcicia (2000, 112) na temat funkcjonowania zliberalizowanych spółdzielni pod koniec lat osiemdziesiątych XX wieku, pozostających pod kontrolą pracowniczą w Słowenii. Okazało się, że zarówno kierownictwo, jak i pracownicy byli pozbawieni motywacji do rozwoju firm. Firmy nie były zainteresowane rozwijaniem inwestycji za granica, natomiast starsze przedsiębiorstwa szybko zdobywały pozycję monopolistyczną i blokowały wejście nowych firm na rynek.

Nota bene taką sytuacje przewidział Mises (1951, 270-275), który ostatecznie doszedł do wniosku, że robotnicy, którzy przejmą władzę nad środkami produkcji, szybko zaczną tworzyć monopolistyczne koncerny i dzielić między sobą dochód narodowy.

Kalecki chcąc zapobiec takiej możliwości, proponował połączyć autonomię rad robotniczych z centralnym planowaniem, którego celem była kontrola: produkcji, inwestycji, płac, zatrudnienia, cen, dystrybucji surowców podstawowych (1956c/1982, 96-98).

Potrafił również nieświadomie oddalić argumentację Misesa o tworzeniu przez robotników monopolistycznych koncernów. Kalecki obawiał się kartelizacji, ale dopuszczał tworzenie tzw. koncernów pionowych, które miałyby znacznie większą autonomię niż zwykłe zakłady (1957d/1982). W idei koncernów pionowych chodziło o łączenie w koncern dużych jednostek danej branży, które byłyby zależne od kupna i sprzedaży półfabrykatów, ale byłyby również względnie samowystarczalne, jeżeli chodzi o zaopatrzenie w materiały i surowce konieczne do wytworzenia gotowych produktów. Koncern taki posiadałby własną radę robotniczą oraz zarząd, który zajmowałby się wewnętrznymi sprawami takiej jednostki kontrolowaniem premii, systemu bodźców i nakazów. Państwo kontrolowałoby dystrybucję surowców podstawowych i mogłoby stosować bodźce w celu regulacji produkcji.

Tym samym polski ekonomista stworzył szereg wskazówek, które rozwiązują wiele praktycznych i teoretycznych problemów gospodarki uspołecznionej. Moim zdaniem trudno jednak uznać to za całościowy model. Trzeba mieć na uwadze, że Kalecki pracował w państwie, gdzie władza miała co najmniej autorytarny charakter, stąd zapewne nie było szans na realizację wszystkich jego pomysłów. Z drugiej strony nie wiadomo, czy sytuacja wyglądałaby inaczej w państwie demokratycznym, gdzie pomysły autora musiałyby zyskać wpierw akceptacje szerokiego gremium ludzi - od polityków po typowy dla współczesnej demokracji rozbudowany aparat urzędniczy.

\section{Gospodarka planowa a niedobory}

Poza pracami przedstawicieli szkoły austriackiej największy wkład w podważenie racjonalności gospodarki centralnej planowanej miały dzieła Janosa Kornaia (1985, 1986a, 1986b, 1992, 2012), który stworzył szeroko dziś znaną teorię gospodarki niedoboru, wedle której braki w zaopatrzeniu spowodowane były nadmiernym popytem. 
Główną innowacją w podejściu węgierskiego ekonomisty było rozróżnienie struktury budżetowej przedsiębiorstw kapitalistycznych i socjalistycznych. Według Kornaia w przedsiębiorstwach kapitalistycznych mamy zazwyczaj do czynienia z budżetem twardym przedsiębiorca w gospodarce kapitalistycznej stale zagrożony jest bankructwem, nie może liczyć na pomoc z zewnątrz, co motywuje go do efektywnego zarządzania firmą. Natomiast w gospodarce realnego socjalizmu miało występować zjawisko miękkich budżetów z powodu po pierwsze wyśrubowanych planów i dążenia do jak najwyższego tempa wzrostu, po drugie - opiekuńczego podejścia państwa do przedsiębiorstw, dzięki czemu nie groziło im bankructwo i inne typowe zagrożenia występujące w gospodarce rynkowej.

W perspektywie kaleckiańskiej z pewnością prawdziwy był pierwszy zarzut. W literaturze poświęconej Kaleckiemu problem przeinwestowania w gospodarce centralnie planowanej jest powszechnie uznawany przez jego zwolenników (Osiatyński1988, 2006, 2015; Kriesler i Haurcort 2014).

Kalecki w swoich pracach zabiegał o zmianę proporcji inwestycji na korzyść konsumpcji. W szczególności zwracał uwagę na kwestię ujemnych bilansów handlowych, które w jego ocenie stanowiły jedną z głównych barier rozwoju polskiej gospodarki (1958, 230-231; 1962, 266-267). Nie zgodziłby się raczej, że lekarstwem na powyższe problemy byłoby urynkowienie i „utwardzenie” budżetów przedsiębiorstw.

Szerzej tę kwestię poruszyła Andrea Szego (1991), która powołując się na polskiego ekonomistę, skrytykowała perspektywę Kornaia. Zdaniem badaczki wobec teorii gospodarki niedoboru można postawić następujące zarzuty: 1) jeżeli kreacja pieniądza kredytowego ma charakter endogeniczny, to miękki budżet charakteryzuje zakłady zarówno kapitalistyczne, jak i socjalistyczne; 2) jeżeli menedżerowie przedsiębiorstw socjalistycznych charakteryzują się nieograniczonym zapotrzebowaniem na dobra inwestycyjne i jednocześnie zawsze potrafia zapewnić sobie płynność potrzebną do realizacji planu, to $\mathrm{w}$ przedsiębiorstwach kapitalistycznych menedżerowie również posiadają wewnętrzną motywację niezależną od interesu właścicieli firm. Jedyna różnica polega na tym, że w kapitalizmie wpływ na politykę firmy mają też udziałowcy.

W odniesieniu do pierwszego zarzutu można przypuszczać, że stał się on mocniejszy wraz z upływem lat. Po pierwsze publikacja zamieszczona w kwartalniku wydawanym przez Bank Anglii (McLeay, Radia i Thomas 2014) dowodzi, że kreacja pieniądza kredytowego zależy od popytu na niego, a nie od stanu bankowych depozytów. Zatem w zgodzie z tym emisja pieniądza kredytowego rzeczywiście miałaby charakter endogeniczny. Zauważył to również Geoffrey Ingham (2004), który analizując historię pieniądza, dowodził, że w kapitalizmie system bankowy powiązany jest z systemem państwowym, aby niemal bez ograniczeń finansować inwestycje wiodących przedsiębiorstw. Tezę tę mogą potwierdzać wydarzenia po wybuchu kryzysu finansowego w Stanach Zjednoczonych w latach 2007-2008. 
Okazało się wówczas, że wiodące podmioty w amerykańskim systemie finansowym są zbyt wielkie, by upaść (too big to fail), a zatem państwo było odpowiedzialne za podtrzymanie przy życiu prywatnych instytucji finansowych. Niemniej jednak - wbrew temu, co sądzi Szego - tego rodzaju miękkie budżety mogą dotyczyć tylko naprawdę dużych podmiotów, które są ważne dla funkcjonowania całego systemu. We współczesnej gospodarce kapitalistycznej zdarzają się bankructwa, zwłaszcza w sektorze małych i średnich przedsiębiorstw, gdzie są jednak zjawiskiem dość powszechnym.

Co do drugiego zarzutu - można powiedzieć, że działania menedżerów w socjalizmie potwierdzaja słuszność propozycji Kaleckiego. W jego perspektywie to nie nadmierna kontrola, lecz jej brak przyczyniał się do słabej kondycji gospodarki centralnie planowanej. Potwierdza to przypuszczenia o konieczności wprowadzenia oddolnej, demokratycznej kontroli robotniczej, a także bardziej efektywnego sposobu nadzorowania przez władze centralne.

Wydaje się więc, że realny socjalizm i realny kapitalizm maja wspólne cechy ochrona dużych, kluczowych dla gospodarki podmiotów, menedżerowie nie zawsze kierujący się interesem właściciela. W teorii przewagą socjalizmu powinno być za to maksymalizacja dobra społecznego. Jednakże chyba nawet w tym zakresie niektóre dobrze rozwinięte gospodarki kapitalistyczne wypadają lepiej, choć trzeba zauważyć, że zachodnie państwa kapitalistyczne z przyczyn historycznych od początku istnienia państw realnego socjalizmu znajdowały się w dużo lepszej sytuacji ekonomicznej. Sytuację gospodarek centralnie planowanych w powiązaniu z tym dodatkowo pogarszała ideologia głosząca, iż zachodnie państwa kapitalistyczne trzeba koniecznie dogonić gospodarczo, przez co zakładane plany stawały się zbyt ambitne i nierealistyczne. Warto może wobec tego przyczyn upadku realnego socjalizmu poszukać poza czystą ekonomią i odwołać się do jej związków z polityką.

Z mojego punktu widzenia w literaturze poświęconej Kaleckiemu zbyt mało miejsca poświęca się kwestii stosunków produkcji w realnym socjalizmie. Trzeba zwrócić uwagę, że polski ekonomista pracował w systemie o charakterze, delikatnie mówiąc, autorytarnym. W związku z tym nie mógł oficjalnie wypowiedzieć się na temat wpływu antagonizmów klasowych na ceny i podział dochodu narodowego w gospodarce planowej, jak to uczynił, analizując dynamikę kapitalizmu. W marksizmie instytucjonalnym tego okresu twierdzono bowiem, że takie antagonizmy nie występuja, a w najlepszym razie maja ograniczony charakter, np. w postaci konfliktu między miastem a wsia.

W literaturze naukowej problematyką konfliktów klasowych w gospodarce centralnie planowanej zajmował się między innymi brytyjski socjolog pracy Bob Arnot (1988), który pisał o zjawisku „negatywnej kontroli robotniczej”. Problem ten pojawiał się, gdy władza chciała zwiększyć wydajność pracowników, nie wprowadzając przy tym nowych technik produkcji i nie zwiększając płac. Pracownicy wówczas uciekali się do rozmaitych form 
„sabotażu” - spowolnienia tempa wykonywanej pracy, strajków, nagminnego korzystania ze zwolnień lekarskich itd. Zdaniem Arnota pozwalało to pracownikom na zachowanie poczucia kontroli nad własną siłą roboczą w obliczu zwiększenia jej zewnętrznej kontroli. W dłuższej perspektywie wpływało to negatywnie na funkcjonowanie całej gospodarki.

Sięgając chociażby do analiz Lwa Trockiego (1937), można spostrzec, że nawet w perspektywie marksisty gospodarka realnego socjalizmu była naznaczona poważnymi sprzecznościami pomiędzy interesami klasy robotniczej a biurokracją. Stanowiła w rozumieniu Trockiego kastę, która dążyła do przekształcenia się w klasę - czyli w marksistowskim rozumieniu z dopuszczającej się nadużyć warstwy zarządzającej środkami produkcji w ich faktycznych właścicieli.

Nie ma tutaj miejsca na przeprowadzenie szczegółowej analizy teorii Trockiego, jednakże historyczny rozwój i upadek Związku Radzieckiego oraz jego państw satelickich zdaje się potwierdzać zasadnicze konkluzje konkurenta Stalina.

W perspektywie Kaleckiego trudno byłoby nie zauważyć, że liczne walki społeczne, chociażby w Polsce Ludowej, nie mogły pozostać bez wpływu na dochód narodowy. Biurokracja była wyalienowana i nie reprezentowała w rzeczywistości interesów klasy, której oficjalnie była przedstawicielem. Silne i niezależne organizacje robotnicze mogłyby naciskać na zwiększenie produkcji środków konsumpcji kosztem inwestycji przeznaczonych na rozbudowę sił wytwórczych. W rezultacie mogłoby to doprowadzić do zmniejszenia niedoborów i polepszenia sytuacji aprowizacyjnej. Podejmowane przez władzę decyzje o usprawnianiu planowania i polepszeniu sytuacji materialnej społeczeństwa przeważnie były spóźnione i źle przygotowane, czego końcowymi efektami były kapitałochłonność oraz powiększenie deficytu handlowego, a także niekorzystny bilans płatniczy. Problemy te stanowiły przedmiot szczególnej uwagi polskiego ekonomisty (1962/1982, 1963/1982, 1964b/1982).

Kalecki, a także Tadeusz Kowalik byli świadomi tych problemów i pragnęli „reformy przełomowej" realnego socjalizmu, która przynieść miała efekt taki jak podobna reforma kapitalizmu po drugiej wojnie światowej (Kalecki i Kowalik 1971; Kowalik 1989).

Gary Dymski (2014) stwierdził wręcz, że powyżsi autorzy swoimi tezami o „reformach przełomowych” kapitalizmu rozwinęli de facto materializm historyczny. Jego zdaniem przemiany, które nastapiły po drugiej wojnie światowej w kapitalizmie, dowodziły, że można zrewolucjonizować stosunki produkcji, nie zmieniając reżimu akumulacji. Oznaczałoby to, że realny socjalizm da się zreformować, jeśli zrezygnuje się z centralnego planowania i wprowadzi mechanizm rynkowy, a jednocześnie zachowa system oparty na pełnym wykorzystaniu mocy produkcyjnych.

Powyższa opinia budzi moje poważne zastrzeżenia. Po pierwsze nie zgadzam się ze stwierdzeniem, że jakakolwiek reforma kapitalizmu „zrewolucjonizowała” stosunki 
produkcji. Choć ustanowienie państwa dobrobytu i oparte na konsensusie współistnienie klas społecznych można uznawać za zjawisko pozytywne, z perspektywy marksistowskiej nie ma to jednak charakteru rewolucyjnego, to znaczy struktura własności środków produkcji nie uległa zmianie. Po drugie z pism samego Kaleckiego jasno wynika, że decentralizacja i urynkowienie realnego socjalizmu nie mogłyby pozostać bez wpływu na reżim akumulacji. W mojej ocenie byłaby to pewnego rodzaju formacja przejściowa wobec pełnej gospodarki kapitalistycznej.

Bliższy poglądom polskiego ekonomisty byłby raczej sceptycyzm wobec trwałości reform na gruncie obu systemów. Efektywne wprowadzenie w życie jego myśli wymagałoby nie reformy, ale w dużej mierze oddolnej, demokratycznej rewolucji politycznej. Pożądanym efektem byłoby więc zdemokratyzowanie systemu politycznego i pobudzenie oddolnej inicjatywy do wprowadzenia innowacji, których brak odczuwał realny socjalizm w konkurencji z kapitalizmem.

Koresponduje to niejako $z$ jednym $z$ podstawowych zarzutów o naturze antropologicznej skierowanym przeciwko gospodarce socjalistycznej, który został dobrze ujęty w jednej z prac Paula Krugmana:

Podstawowy problem nie był natury technicznej, lecz moralnej. Komunizm zawiódł jako system gospodarczy, ponieważ ludzie przestali w niego wierzyć (...). Możesz nie lubić kapitalizmu, a nawet czuć, że system ten w końcu upadnie, jednocześnie wykonując swoją pracę, ponieważ twoja rodzina potrzebuje pieniędzy, które zarabiasz. Kapitalizm może działać, a nawet rozkwitać w społeczeństwie samolubnych cyników. Jednak nie może być tak w gospodarce nie-rynkowej. Osobiste bodźce, które maja sprawiać, że pracownicy będą dobrze wykonywać swoją pracę, a menedżerowie podejmować dobre decyzje sa po prostu zbyt słabe. W ostatnich latach istnienia Związku Radzieckiego robotnicy zdawali sobie sprawę z tego, że dostaną zapłatę niezależnie od włożonego wysiłku, podobnie menedżerowie wiedzieli, że ich awans zależy bardziej od koneksji politycznych niż od ich wydajności; nikt też nie otrzymywał na tyle wysokich nagród, które kompensowałyby zajmowanie niepopularnych stanowisk i podejmowanie ryzyka (1997).

Wypowiedź Krugmana można zinterpretować jako swego rodzaju krytykę polityczną, która uwidacznia, jak istotna jest kwestia postulowanej przez Kaleckiego partycypacji robotników w zarządzaniu gospodarką socjalistyczną. Wydaje się, że brak wolności politycznej umożliwiającej producentom współdecydowanie o sposobie podziału wytworzonego przez siebie dochodu jest czynnikiem podkopującym wiarę w sprawiedliwość i efektywność takiego systemu. W realnym socjalizmie przy jedynie formalnym uspołecznieniu produkcji, po porzuceniu stalinowskiej, surowej dyscypliny w miejscu pracy robotnicy nie posiadali zbyt wielu bodźców do zwiększenia swojej wydajności. Przy wysoce scentralizowanym systemie 
planowania interesy robotników zainteresowanych zwiększeniem konsumpcji i ogólnego dobrobytu musiały przeciwstawiać się interesom biurokracji partyjnej nastawionej głównie na realizację inwestycję doniosłych głównie pod względem politycznym.

Rację ma amerykański ekonomista, że w gospodarce nierynkowej jednostkowe, osobiste bodźce i motywacje mogą być zbyt słabe, żeby gospodarka ta rozwijała się poprawnie. Dlatego w takim systemie dużo większą rolę mogą odegrać „bodźce kolektywne” odwołujące się do wspólnoty interesów i współodpowiedzialności producentów za losy gospodarki, którą tworzą. W związku z tym proponowane przez wielu marksistowskich ekonomistów wizje realnego uspołecznienia, tzn. rzeczywistej kontroli klasy robotniczej nad środkami produkcji, są dużo bardziej adekwatną odpowiedzią na zarzuty natury antropologicznej. Rzecz jasna z samego faktu przejęcia kontroli nad środkami produkcji przez robotników nie wynika, że wiara w tworzony przez nich system będzie trwała. Trzeba zgodzić się z Krugmanem, a także z Kaleckim, że główny problem gospodarki socjalistycznej nie leży w optymalnym modelu czy też sposobie kalkulacji. Podstawowym warunkiem jej powodzenia jest stworzenie takiej wspólnoty politycznej, która uzasadniałaby wiarę jej członków w racjonalność obranych przez nią rozwiązań ekonomicznych.

\section{Zakończenie}

W artykule przedyskutowałem najważniejsze tezy Kaleckiego i jego zwolenników odnośnie do funkcjonowania gospodarki rynkowej i gospodarki centralnie planowanej w kontekście sporów o racjonalność socjalizmu.

Z argumentacji Demirbaga i Haleviego wynika, że rola wiedzy niejawnej może być zdecydowanie przeceniana i nie można jej przypisać takiego znaczenia, jakie przypisywał jej Hayek. Nie odgrywa ona kluczowej roli ani w kapitalizmie, ani w socjalizmie, ponieważ w zasadzie ceny w obu systemach ustalane są odgórnie. Wpływ czynników oddolnych na ceny w obu systemach nie jest efektem aktywności autonomicznych jednostek transmitujących w ten sposób nieskodyfikowaną wiedzę, lecz zorganizowanej walki klasowej, przejawiającej się w aktywności związków zawodowych tudzież potencjalnie innych instytucji pracowniczych, np. rady robotniczej.

Ponadto uwagi polskiego ekonomisty o sposobie tworzenia cen zaprzeczaja twierdzeniu Misesa o naturalnej tendencji socjalizmu do izolacji gospodarczej. Kalecki w odróżnieniu od Langego oraz wielu współczesnych socjalistów nie przywiązywał także dużej wagi do stworzenia kompletnego modelu gospodarki socjalistycznej. Bardziej zależało mu na pragmatycznym rozdziale kompetencji pomiędzy biurokrację a klasę robotniczą adekwatnie do bieżących potrzeb. W tej perspektywie niedobór w gospodarce planowanej był problemem nie tylko przeinwestowania, lecz przede wszystkim złego systemu politycznego 
i braku autentycznej partycypacji pracowników w procesie zarządzania formalnie tylko uspołeczniona gospodarką.

W tym kontekście trudno zgodzić się z opinią Kazimierza Laskiego (2014), że Kalecki nigdy nie był marksista. Wydaje mi się, że wręcz przeciwnie. Był bliższy marksizmowi bardziej niż twórcy systemu, który próbował naprawić. 


\section{Wykaz literatury}

Adaman, Fikret i Pat Devine. 1997. „On the Economic Theory of Socialism.”, New Left Review 221: 54-80.

Adaman, Fikret i Pat Devine. 2002. „A Reconsideration of the Theory of Entrepreneurship: A Participatory Approach", Review of Political Economy 23: 329-355.

Adaman, Fikret i Pat Devine. 2006. „The Promise of Participatory Planning. Rejoinder to Hodgson." Economy and Society 35: 141-147.

Albert, Micheal i Robert Hehnel. 1992. „Participatory Planning.” Science and Society 56: 39-59.

Albert, Micheal i Robert Hehnel. 2002. „In Defence of Participatory Economics.” Science and Society 66: 7-21.

Arestis, Philip. 1996. „Kalecki's Role in Post-Keynesian Economics: An Overview.” W An Alternative Macroeconomic Theory. The Kaleckian Model and Post-Keynesian Economics, red. J.E King. Dordrecht: Kluwer

Arnot, Bob. 1988. Controlling Soviet Labour. Experimental Change from Breznhev to Gorbachev. New York: M.E. Sharpe.

Auerbach, Paul i Dmitris Sotiropoulos. 2014. „Revisiting the Socialist Calculation Debate. The Role of Markets and Finance in Hayek's Response to Lange's Challenge." W Economic Crisis and Political Economy: Volume II of Essays in Honour of Tadeusz. Kowalik, red. Ewa Karwowska i Jan Toporowski. New York: Palgrave Macmillan.

Ban, Cornel. 2012. „Sovereign Debt, Austerity, and Regime Change: The Case of Nicolae Caucescu's Romania.” East European Politics \& Societies 26: 743-776.

Barone, Enrico. 1935. „The Ministry of Production in the Collectivist State.” W Collectivist Economic Planning, red. Friedrich Hayek. London: Routledge.

Bhaduri, Amit. 2014. „Effective Demand and Path Dependence in Short-and-long-run Growth.” W Michal Kalecki in 21 st Century, red. Jan Toporowski i Lukasz Mamica. New York: Routledge.

Boettke, Peter. 2002. Calculation and Coordination. Essays on Socialism and Transitional Political Economy. London: Routledge.

Böhm-Bawerk, Eugen. 1975. Karl Marx and the Close of His System. A Criticism. Clifton: Augustus M. Kelley.

Chilosi, Alberto. 2004. „Kalecki’s Theory of Income Determination and Modern Macroeconomics. A Reconstruction and an Assessment." W Kalecki's Economics Today, red. Zbigniew Sadowski i Adam Szeworski. London: Routledge.

Cotrell, Alin i Paul Cockshott. 1993. Toward a New Socialism. Nottingham: Spokesman.

De Soto, Huerta. 2010. Socialism, Economic Calculation and Entrepreneurship. Chaltencham: Edward Elgar.

Devine, Pat. 1992. „Market Socialism or Participatory Planning?”, Review of Radical Political Economy 24: 67-89.

Dyker, David. 2011. Yugoslavia. Socialism, Developement and Debt. New York: Routledge. 
Dymski, Gary. 2014. „Kalecki and Kowalik on the Dilemma of «Crucial Reform»”” W Kalecki's Economics Today, red. Zbigniew Sadowski i Adam Szeworski. New York: Routledge.

Hayek, Friedrich. 1996. Droga do zniewolenia. Tłum. zbiorowe. Kraków: Arcana.

Hayek, Friedrich. 1945. „The Use of Knowledge in Society.” American Economic Review 35: 519-530.

Hayek, Friedrich. 1949. „The Competetive «Solution».” W Individualism and Economic Order, red. Friedrich Hayek. London: Routledge.

Hockuba, Zbigniew i Marek Brzeziński. 2005. „Oskara Langego syntezy teorii ekonomicznych.” W Oskar Lange a wspótczesność, red. Zbigniew Sadowski. Warszawa: Polskie Towarzystwo Ekonomiczne.

Hodgson, Goefrey. 1998. „Socialism against Markets? A Critique of Two Recent Proposals.” Economy and Society 27: 407-433.

Hodgson, Goefrey. 2005. „The Limits to Participatory Planning. A Reply to Adaman and Devine." Economy and Society 34: 141-153.

Ingham, Geofrey. 2004. The Nature of Money. Cambridge: Polity Press.

Jossa, Bruno. 2014. Producer Cooperatives as a New Form of Production. New York: Routledge.

Kalecki, Michał. 1942/1982. „Warunki powstania demokratycznej gospodarki planowej.” W idem, Drieła, t. 3, red. Jerzy Osiatyński. Warszawa: Państwowe Wydawnictwo Ekonomiczne.

Kalecki, Michał. 1943/1979. „Polityczne aspekty pełnego zatrudnienia.” W idem, Dzieła, t. 1, red. Jerzy Osiatyński. Warszawa: Państwowe Wydawnictwo Ekonomiczne.

Kalecki, Michał. 1946a/1982. „Uwagi o racjonowaniu i systemie cen.” W idem, Drieła, t. 3, red. Jerzy Osiatyński. Warszawa: Państwowe Wydawnictwo Ekonomiczne.

Kalecki, Michał. 1946b/1982. „Uwagi o oszczędnościach i obiegu pieniężnym w Polsce.” W idem, Drieła, t. 3, red. Jerzy Osiatyński. Warszawa: Państwowe Wydawnictwo Ekonomiczne.

Kalecki, Michał. 1946c/1982. „Plany finansowe na II półrocze 1946 r. i na I półrocze 1947 r.” W idem, Drieła, t. 3, red. Jerzy Osiatyński. Warszawa: Państwowe Wydawnictwo Ekonomiczne.

Kalecki, Michał. 1947/1982. „Alokacja zasobów a ceny.” W idem, Diieła, t. 3, red. Jerzy Osiatyński. Warszawa: Państwowe Wydawnictwo Ekonomiczne.

Kalecki, Michał. 1954/1980. „Teoria dynamiki gospodarczej.”. W tegoż idem, Dzieła, t. 2, red. Jerzy Osiatyński. Warszawa: Państwowe Wydawnictwo Ekonomiczne.

Kalecki, Michał. 1956a/1982. „Liberalizacja zarządzania drobnym przemysłem.” W idem, Drieła, t. 3, red. Jerzy Osiatyński. Warszawa: Państwowe Wydawnictwo Ekonomiczne.

Kalecki, Michał. 1956b/1982. „Bodźce w gospodarce socjalistycznej.” W idem, Drieła, t. 3, red. Jerzy Osiatyński. Warszawa: Państwowe Wydawnictwo Ekonomiczne.

Kalecki, Michał. 1956c/1982. „Rady robotnicze a centralne planowanie.” W idem, Drieła, t. 3, red. Jerzy Osiatyński. Warszawa: Państwowe Wydawnictwo Ekonomiczne.

Kalecki, Michał. 1957a/1982. „Nie przeceniać roli modelu.” W idem, Dqieła, t. 3, red. Jerzy Osiatyński. Warszawa: Państwowe Wydawnictwo Ekonomiczne. 
Kalecki, Michał. 1957b/1982. „Uwagi o cenach surowców podstawowych.” W idem, Drieła, t. 3, red. Jerzy Osiatyński. Warszawa: Państwowe Wydawnictwo Ekonomiczne.

Kalecki, Michał. 1957c/1982. „Schemat nowego systemu bodźców i nakazów.” W idem, Drieła, t. 3, red. Jerzy Osiatyński. Warszawa: Państwowe Wydawnictwo Ekonomiczne.

Kalecki, Michał. 1957d/1982. „Koncern pionowy jako element nowego modelu gospodarczego.” W idem, Drieła, t. 3, red. Jerzy Osiatyński. Warszawa: Państwowe Wydawnictwo Ekonomiczne.

Kalecki, Michał. 1958a/1982. „Centralistyczne tworzenie cen jako istotna cecha gospodarki socjalistycznej.” W idem, Drieła, t. 3, red. Jerzy Osiatyński. Warszawa: Państwowe Wydawnictwo Ekonomiczne.

Kalecki, Michał. 1958b/1982. „O cenach surowców podstawowych.” W idem, Drieła, t. 3, red. Jerzy Osiatyński. Warszawa: Państwowe Wydawnictwo Ekonomiczne.

Kalecki M. 1959/1982. „Z zagadnień teorii dynamiki gospodarki socjalistycznej.” W idem, Drieła, t. 3, red. Jerzy Osiatyński. Warszawa: Państwowe Wydawnictwo Ekonomiczne.

Kalecki, Michał. 1962a/1982. „Problemy własnej bazy cen krajów RWPG.” W idem, Drieła, t. 3, red. Jerzy Osiatyński. Warszawa: Państwowe Wydawnictwo Ekonomiczne.

Kalecki, Michał. 1962b/1982. „Zarys metody konstruowania planu perspektywicznego.” W idem, Drieła, t. 3, red. Jerzy Osiatyński. Warszawa: Państwowe Wydawnictwo Ekonomiczne.

Kalecki, Michał. 1963/1982. „O podstawowych zasadach planowania wieloletniego.” W idem, Drieła, t. 3, red. Jerzy Osiatyński. Warszawa: Państwowe Wydawnictwo Ekonomiczne.

Kalecki, Michał. 1964a/1982. „Sprawozdanie zespołu do opracowania niektórych problemów związanych z rola zysku i cen fabrycznych oraz zakresu stosowania tych cen w planowaniu i systemie finansowym.” W idem, Drieła, t. 3, red. Jerzy Osiatyński. Warszawa: Państwowe Wydawnictwo Ekonomiczne.

Kalecki, Michał. 1964b/1982. „Uwagi o planie gospodarczym na lata 1966-1970.” W idem, Drieła, t. 3, red. Jerzy Osiatyński.. Warszawa: Państwowe Wydawnictwo Ekonomiczne.

Kalecki, Michał. 1971/1980. „Walka klas a podział dochodu narodowego.” W idem, Drieła, t.2, red. Jerzy Osiatyński. Warszawa: Państwowe Wydawnictwo Ekonomiczne.

Kalecki, Michał i Tadeusz Kowalik. 1971/1980. „Uwagi o «reformie przełomowej».” W Michał Kalecki, Drieła, t. 2, red. Jerzy Osiatyński. Warszawa: Państwowe Wydawnictwo Ekonomiczne,

Kołodko, Grzegorz i Walter Mc Mahon. 1987. „Stagflation and Shortageflation. A Comparative Approach.” Kyklos 40: 176-197.

Kornai, Janos. 1985. Niedobór w gospodarce. Tłum. Urszula Grzelońska i Zofia Wiankowska. Warszawa: Państwowe Wydawnictwo Ekonomiczne.

Kornai, Janos. 1986a. W Zrost, niedobór, efektywność. Makrodynamiczny model gospodarki socjalistycznej. Tłum. Zofia Wiankowska. Warszawa: Państwowe Wydawnictwo Ekonomiczne.

Kornai, Janos. 1986b. „The Soft Budget Constraint.” Kyklos 39: 3-30.

Kornai, Janos 1992. The Socialist System. The Political Economy of Communism. Oxford: Oxford University Press. 
Kornai, Janos. 2012. „What Economics of Shortage and The Socialist System Have to Say to the (Hungarian) Readers Today: An Introductory Study to the First Two Volumes of the Live's Work Series." Acta Oeconomica 62: 365-384.

Kowalik, Tadeusz. 1989. „Toward a Mixed Socialist Economy.” International Journal of Political Economy 19: 56-77.

Kowalik, Tadeusz 1994. „Oskar Lange's Market Socialism. The Story of an Intellectual Political Career." W Why Market Socialism?, red. Franklin Roosevelt i David Belkin. New York: M.E. Sharpe.

Kowalik, Tadeusz. 2004. „Oskar Lange - między socjalizmem a kapitalizmem.” W Twórczość naukowa Oskara Langego i jej znaczenie w teorii ekonomii, red. Grzegorz Musiał. Katowice: Akademia Ekonomiczna im. Karola Adamieckiego w Katowicach.

Kowalik, Tadeusz. 2005. „Teoria socjalizmu Oskara Langego w konfrontacji z realiami.” W Oskar Lange a wspótczesność, red. Zdzisław Sadowski. Warszawa: Polskie Towarzystwo Ekonomiczne.

Kowalik, Tadeusz. 2012. Róża Luksemburg. Teoria akumulacji i imperializmu. Warszawa: Książka i Prasa.

Krawczyk, Rafał. 1990. Wielka przemiana. Upadek i odrodzenie polskiej gospodarki. Warszawa: Oficyna Wydawnicza.

Kreisler, Peter i Geoff Harcourt. 2014. „The Failure of Economic Planning. The Role of the Feldman Model and Kalecki's Critique." W Michal Kalecki in 21st Century, red. Jan Toporowski i Łukasz Mamica. New York: Routledge.

Krugman, Paul. 1997. „Capitalism’s Mysterious Triumph.” http://web.mit.edu/krugman/www/Russia.htm.

Lavoie, Don. 1985. Rivalry and Central Planning. A Re-Examination of The Debate Over Economic Calculation Under Socialism. Cambridge: Cambridge University Press.

Lavoie, Don i Peter Boettke. 2011. Rivalry and Central Planning. New York: Routledge.

Łukawer, Edward 2005. Spór o racjonalność gospodarki socjalistycznej. Kraków: Polskie Towarzystwo Ekonomiczne.

Lange, Oskar. 1973a. „O ekonomicznej teorii socjalizmu.” W idem, Drieła, t. 2, red. Mieczysław Jagielski. Warszawa: Państwowe Towarzystwo Ekonomiczne.

Lange, Oskar. 1973b. „Maszyna licząca i rynek.” W idem, Dįieła, t. 2, red. Mieczysław Jagielski. Warszawa: Polskie Towarzystwo Ekonomiczne.

Laski, Kazimierz. 2009. Mity i rzecsywistość w polityce gospodarczej i w nauczaniu ekonomii. Warszawa: Instytut Nauk Ekonomicznych Polskiej Akademii Nauk.

Laski, Kazimierz i Herbert Walther. 2014. „Kalecki’s Profits Equation after 80 Years.” W Michal Kalecki in 21st Century, red. Jan Toporowski i Lukasz Mamica. New York: Routledge.

Mandel, Ernest. 1986. „In Defence of Socialist Planning.” New Left Review 159: 5-37.

Mandel, Ernest. 1988. „The Myth of Market Socialism.” New Left Review 169: 108-120.

McCleay Michael, Amar Radia i Thomas Ryland. 2014. „Money Creation in the Modern Economy.” Bank of England Quarterly Bulletin 1: 14-27. 
Michell, Jo. 2014. „The Price Mechanism and the Structure of Income in Kalecki's Economics and Post-Kaleckian Economics." W The Legacy of Rosa Luxemburg, Oskar Lange and Michat Kalecki: Volume I of Essays in Honour of Tadeusz. Kowalik, red. Jan Toporowski i Łukasz Mamica. New York: Routledge.

Mises, Ludvig. 2012. Kalkulacja ekonomiczna w socjalizmie. Tłum. Jan Jabłecki. Warszawa: Instytut Misesa.

Mises, Ludvig. 1951. Socialism. An Economic and Sociological Analysis. Yale: J. Cape.

Petrin, Tea i Ales Vahcic. 2002. „Employee Involvement and the Modern Firm.” W Equality, Participation, Transition. Essays in Honour of Branko Horvat, red. Vojislav Franicevic i Milica Uvalic. London: St. Martins Press.

Nuti, Marco. 1986. „Michal Kalecki's Contribution to the Theory and Practice of Socialist Planning." Cambridge Journal of Economics 10: 333-353.

Osiatyński, Jerzy. 1982. „Dodatek 4.” W Michał Kalecki, Drieła, t. 3, red. Jerzy Osiatyński. Warszawa: Państwowe Wydawnictwo Ekonomiczne.

Osiatyński, Jerzy. 1988. Michał Kalecki o gospodarce socjalistycznej. Warszawa: Państwowe Wydawnictwo Naukowe.

Osiatyński, Jerzy. 2006. „Michał Kalecki (1899-1971).” Gospodarka Narodowa 6: 1-30.

Osiatyński, Jerzy. 2015. „Kalecki a «złota reguła akumulacji».” Ekonomista 4: 453-463.

Polanyi, Michael. 1962. Personal Knowledge. Towards a Post-critical Philosophy. Chicago: University of Chicago Press.

Polanyi, Michael. 1967. The Tacit Dimension. New York: University of Chicago Press.

Reynolds, Peter J. 1996. „Kalecki's Theory of Prices and Distribution.” W An Alternative Macroeconomic Theory. The Kaleckian Model and Post-Keynesian Economics, red. W.J. Samuels i W. Darrity. Dordrecht: Kluwer.

Robbins, Lou. 2007. The Great Depression. London: Ludvig von Mises Institute.

Sardoni, Claudio. 2011. Unemployment, Recession and Effective Demand. The Contributions of Marx, Keynes and Kalecki. Cheltencham: Edward Elgar.

Stiglitz, Joseph. 1996. Whither Socialism? Cambridge: Cambridge University Press.

Szego, Andrea. 1992. „The Logic of a Shortage Economy. A Critique of Kornai from a Kaleckian Macroeconomic Perspective." Journal of Post-Keynesian Economics 13: 328-336.

Temkin, Gabriel. 2008. Dyskusje o gospodarce socjalistycznej. Marks-Lange-Mises-Hayek. Warszawa: Polskie Towarzystwo Ekonomiczne.

Toporowski, Jan. 1992. „Two Enigmas in Kalecki's Methodology.” History of Economics Review 16: 90-96.

Toporowski, Jan. 1996. „Kalecki, Marx and the Economics of Socialism.” W An Alternative Macroeconomic Theory. The Kaleckian Model and Post-Keynesian Economics, red. John E. King. Dordrecht: Kluwer.

Toporowski, Jan. 2004. „Kalecki’s Arguments for Socialism.” W Kalecki’s Economics Today, red. Zdzisław Sadowski i Adam Szeworski. New York: Routledge.

Trocki, Lew. 1937. The Revolution Betrayed. What is the Soviet Union and Where is it Going? Detroit: Labor Publications. 
Damian Winczewski - absolwent filozofii na Uniwersytecie Gdańskim. Obecnie doktorant filozofii na Uniwersytecie Szczecińskim, gdzie przygotowuje rozprawę poświęconą Róży Luksemburg. Zajmuje się filozofią marksistowską oraz heterodoksyjną ekonomia polityczną.

\section{DANE ADRESOWE:}

Wydział Humanistyczny

Uniwersytet Szczeciński

ul. Krakowska $71-79$

71-017 Szczecin

EMAIL: damian.winczewski@gmail.com

CYTOWANIE: Winczewski, Damian. 2017. Michał Kalecki i problem racjonalnej alokacji zasobów w socjalizmie. Praktyka Teoretyczna 2(24): 196-225.

DOI: $10.14746 /$ prt.2017.2.9

\section{AUTHOR: Damian Winczewski}

TITLE: Michał Kalecki and the Problem of Rational Allocation of Resources in Socialism

ABSTRACT: The aim of this article is the reconstruction of the views of Michael Kalecki and his followers on rational calculation and allocation of resources in a socialist economy, and also to try to compare their statements with the views of both supporters of capitalism, as well as alternative models of socialism. In this matter the piece examines articles of Polish economists on the pattern formation of prices in capitalism and socialism, the role of the working class and the system of incentives and economic governance. In this paper, we have also discussed the views of the authors who, based on the work of Kalecki, took up a controversy with a circulation narrative explaining the failure of socialism. The conclusion that flows from the preceding analysis is as follows: Real capitalism and real socialism struggle with problems of imperfect information, and soft budgets; a particular model of economic management in this regard is not the direct cause of the failure of the socialist project. In addition to the problem of innovation and optimal investment, from the Kaleckian perspective, a fundamental problem of socialism appears to be the appropriate relations of production in the Marxist sense, understood as democratization of the relationship between the working class and the production management layer.

KEYWORDS: central planning, price regulation, investment, allocation of resources. 